\begin{tabular}{ll}
\hline 資 & 料 \\
\hline
\end{tabular}

\title{
酢酸繊維素用染料の最近の傾向 (2)（アゾ染料）
}

東京工業大学 內 标 光

篚者らはささに 1948 年迄注1以特許文献として現わ れたアゾ系酶酸緎維菜用染料化ついて考察分類を行。 たが，その後 1955 年迄に文献现われた染料をこの 分類に従って整理し，この分類似入らない新部属の染

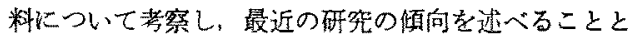
した。

重ず染料をモノブ゙染料とジスアゾ染料，ポリアジ 染料比大別し，各及を所謂不溶性染料々可溶性染料に 分けて述べるのが適当と思われるがジスアン染料，ポ リアゾ染料にはみるべきすが少ないので交献の所在 のみを記すにとどめた。また顕色染料については本稿 では触れないこととした。

[I]モノアソ染料 A. 不溶性染料 不豁性ない 乙難溶性染料として次のものがある

(1) $-\mathrm{NO}_{2},-\mathrm{Cl},-\mathrm{OH},-\mathrm{OCH}_{3},-\mathrm{NH}_{2},-\mathrm{NHCH}_{3},-\mathrm{N}$ $\left(\mathrm{CH}_{3}\right)_{2},-\mathrm{NHCOCH}_{3}$ などの䁌换基のみをるつるの

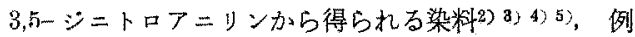

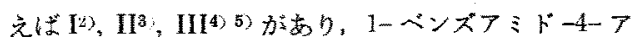
ミノベンゼン誘導体と $p$ クレゾールから得られる染 料早，例之壮IVがある。

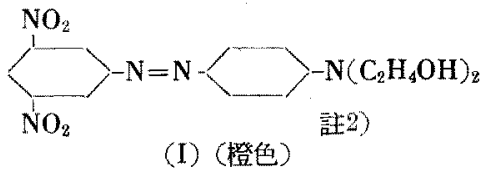<smiles>CC(N)CCN=Nc1cc([N+](=O)[O-])c[n+]([O-])c1</smiles>

(II) (黄色)<smiles>CC(N)CCC(C)N=Nc1ccc([N+](=O)[O-])cn1</smiles>

(III)

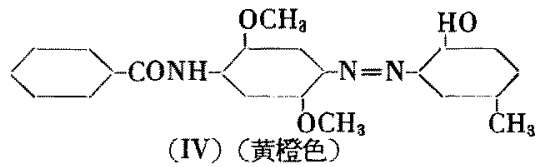

(2) -F，-CF名などをっているもの ジフ成分 の核に一- $\mathrm{CF}_{3}$ をるつモノフ染料で拔染可能な日光, 洗濯，ガス等慳牢な $p^{-}$二トロ - - -トリフルオルィ チルベンゼンーアゾ $\mathrm{N}-$ 才キシアルキルアニリン類り

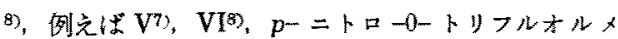
チルペンゼンーアゾ-N-B-シフノエチルーN-オキンア ルキルアニリンタ，例充ばVII が報告され，アゾ成分 にフルオルアルキル基をるつ染料として日光，ガスに 堅寉な二トロフェニルーフダーN-シフルオルフルキル -N-オキシフルキルアニリン類10) 1)，例之ばVIII 109， $\mathrm{IX}^{11)}$, ニトロフェルーフソ $\mathrm{N}-$ トリフルオルアルキ ルーN-オキシアルキルアニリン12)，例点ば X, 4- $[2,4$ ービス(メチルスルホニル) フェニルアゾーN-フルオ ルアルキルーN-オキシアルキルフニリン類13，例克 ばXI が報告されている。アタ成分，ジフソ成分の网 成分にフルオルフルキル基をいった日光，ガス汇堅审 な染料14，例之ば XII がある。<smiles>CCC1CCN(CC=CCOCCO)CC1</smiles>
(V) (ルービン色)<smiles>CCN(CC)C1CCC(N=NC(Cl)C2CC(Cl)CC([N+](=O)[O-])C2)CC1</smiles>
(VI) (褐橙色)

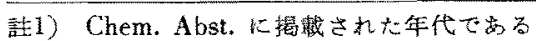

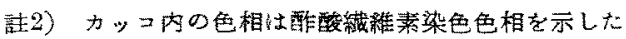


<smiles>N#CCN(C=CO)C1CCN(N=NC2CCC([N+](=O)[O-])CC2C(F)(F)F)CC1</smiles>

(VII)<smiles>O=[N+]([O-])C1CCC(N=NC2CCC(N(CC(F)F)CC(O)C(F)F)CC2)CC1</smiles><smiles>OCCN(CC(F)[In])C1CCC(N=NC2CCCCC2)CC1</smiles>

(IX) (緋 色)<smiles>O=C(O)CN(CC(F)(F)F)C1CCN(N=NC(Cl)C(Cl)CC[N+](=O)[O-])CC1</smiles>

(X)

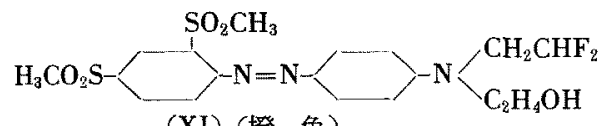
(XI) (橙 色)<smiles>O=[N+]([O-])C1CCC([18F])C(N=NC2CCC(N(CC(F)F)CC(F)F)CC2)C1</smiles>

(XII) (带褐橙色)

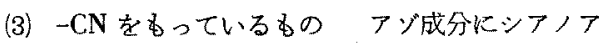
ルキル基をるっているるの ${ }^{15}$ ，例觉ば XIII， $p$-ニト ロー0ーブロムフェニルーフソ-N-シアノアルキルアニリ

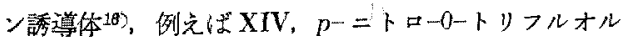
メチルフェニルアソーN-B-シアノェチルーN-オキシア ルキルアニリン類17》，4-[2,4ービス(メチルスルホニル) フェニルアソ〉-N-オキシアルキルーN-シアノエチル アニリン類18)がある。<smiles></smiles><smiles>N#CCN(CCO)C1CCN(N=NC2(Br)CC([N+](=O)[O-])CCC2Br)CC1</smiles>

(XIV) (黄褐色)

(4) 側鎖に一 $-\mathrm{NO}_{2}$ をるっているすの アゾ成分に N

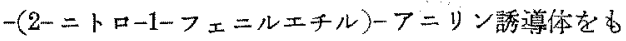

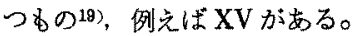

（5）オキッアルキル基などをるっているもの Nオキシアルキルアニリンをジアン成分として用いたす

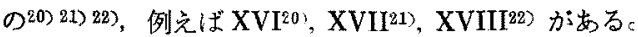

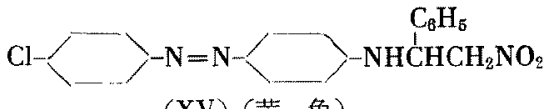

(XV) (黄 色)<smiles>O=[N+]([O-])C1CCC(N=NC2CCN(CCO)CC2)C(Cl)C1</smiles>

(XVI)
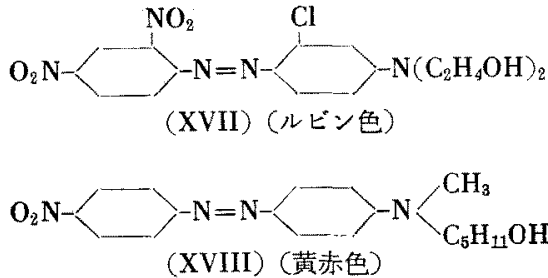

(6) プロピオンオキシド，ホルミリデンジオキソラ ンプロピル基などのあるもの特記すべき報告なし、

(7) アルデヒド基をるっているもの特記すべき 報告なし。

（8）ケトン基をもっているすの 特記すべき報告 なし。

（9）醌酸エステル型のもの 特記すべき報告なし，

(10) カルポン酸エステル基をもっているすの フ ソ成分に N-(カルボキシアルキル)-N-(オキッアルキ ル)ーフニリンのメチルェステル類を用いたるの施，例 えばXIXが日光に堅安な染料として報告されている。<smiles>CC(=O)OCC(C)N(CCCO)C1CCC(N=NC2CCC([N+](=O)[O-])CC2)CC1</smiles>

(11) 炭酸エステル基をもっているもの 特記ずべ き報告なし。

(12) スルホン， $-\mathrm{SO}_{2} \mathrm{R}$ 結合をるっているるの 黄 色，橙色染料としてシアゾ成分中にアルキルスルホ二 ル基をもち，フジ成分中以 $\mathrm{N}$-シアノアルキル基をる つもの゙，例亲ばXXがあり，シアゾ成分中にェチル スルホニル基をるちアゾ成分にテトラヒドロキノリン

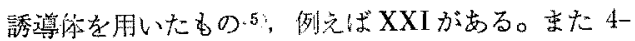
[2,4-ビス(メチルスルホニル)>ェニルアゾ $]-\mathrm{N}-(7$ 
ルオルアルキル) $-\mathrm{N}-\left(\right.$ オキシアルキル)アニリン類 ${ }^{13)}$, 例えばXI，4-[2,4-ビス(メチルスルホニル)フェニル

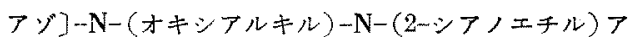
ニリン類 ${ }^{26)}$ ，例えばXXIIが日光，ガスに堅牢な染料 として報告されている。<smiles>CCN(CC)C1CCC(N=NC(Cl)C(C)O)CC1CC(C)(C)O</smiles><smiles>CCOS(=O)C1CC([N+](=O)[O-])CC(N=NC2CCC3=NC(C)(C)C(O)C(O)(O)C(C)C3C2)C1[N+](=O)[O-]</smiles>
(XXI) (青色) $\stackrel{i}{\mathrm{C}} \mathrm{H}_{2} \mathrm{CH}(\mathrm{OH}) \mathrm{CH}_{2} \mathrm{OH}$

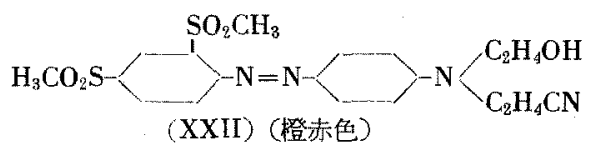

(13) 核の一員としてSのあるもの ジアゾ成分に

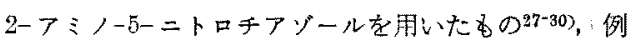
えば XXIIT2728)，XXIV201，XXV30)がありこれらは 日光がスに堅恕である。<smiles>C#[C+]CN(CC)CC1CCC(N=Nc2ncc([N+](=O)[O-])s2)C1</smiles><smiles>COC1CC(N=Nc2ncc([N+](=O)[O-])s2)CC(Cl)C1NCC(O)CO</smiles>
（XXIV) (带赤青色)<smiles>CCCCN(CCC)CCC(C)C(N=[W])=NNc1ncc([N+](=O)[O-])s1</smiles>

ジアゾ成分にちーアミノー1, 2, H一チアジアグール類を

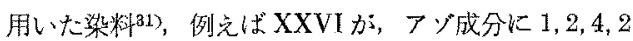

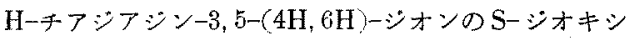
ドを用いたもの福，例えばXXVIIが報告されている。

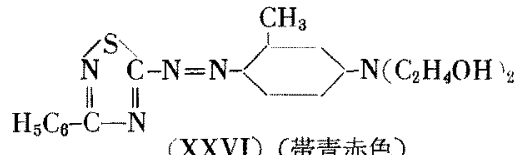
（XXVI）（带等赤色）<smiles>O=C1NCC(N=NC2CCCCC2)C(=O)NC1=O</smiles>

(XXVII)

(14) シクロへキシル慕，テトラヒドロフルフリル基 などをるっているるの 特記すべき報告なし。

(15) $-\mathrm{COCH}_{2} \mathrm{CO}$-結合をもっているもの アソ成 分としてアセチルアセトフニリド類が用いられている

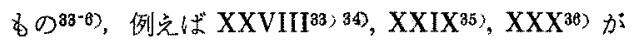
日光に堅安な染料として報告されている。<smiles>COC1CC(NC(=O)C(N=NC2CCC(Cl)CC2C)C(C)=O)C(Cl)CC1NC(C)=O</smiles>
(XXVIII) (黄 色)<smiles>COC1CC(Cl)CCC1N=NC(C(C)=O)C(=O)NC1CC(OC)C(NC(C)=O)CC1Cl</smiles>

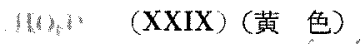<smiles>COC1CC(NC(=O)C(N=NC2CCC(Cl)CC2C)C(C)=O)CC(OC)C(C#N)C1</smiles>

(XXX)（輝带粶演色）

(16) 核の一員としてN 1 原子あるるの アソ成分 として4ーオキシー2(1H)ーキノロンを用いたすのる7)，例 えばXXXIがあり，日光，ガス，洗翟に堅军である。 アゾ成分にテトラヒドロキノリン誘導梌用いたす

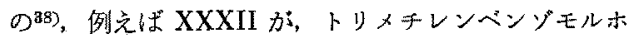
リン類を用いたのの帛，例光ばXXXIIIが報告されて いる。

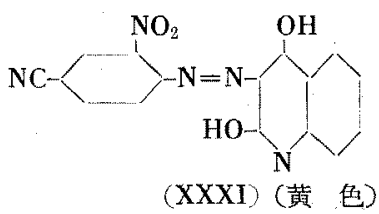

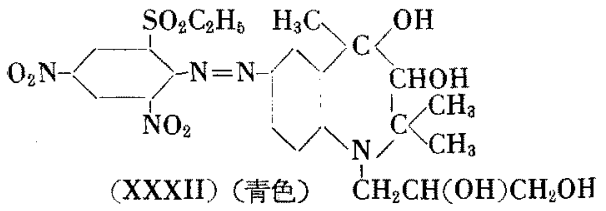


<smiles>[2H]C1CC2CCCC3OCC(C)CC3N2C(C)C1O</smiles>

(11) 核の一員としてN2原子あるものジアゾ成 分として4,6-ジオキシピりミシン類を用いた黄色染 料40)，例党ばXXXIVがある。

(18)，側鎖に一- $\mathrm{CH}=\mathrm{CH}-$ 結合のあるもの アゾ成分 に 1,3-ブタジェン基をもったるの ${ }^{41}$ ，例えば XXXV があり水洗堅牟度がすぐれている。<smiles>CCOC1CCCCC1N=NC1COCC(C)NC(=O)C1</smiles>
(XXXIV) (黄色)<smiles>CC=CCC(=CCCC)N1CCCC(NC2CCCCC2)CC1</smiles>
(XXXV)

(19) クロム含有アゾ染料特記すべき報告なし。 (20) $-\mathrm{CONH}_{2}$ むっているすのこれらは多少可 溶性であるが分散凧の添加が必要なものが多いので不 溶性染料に分類することとした。アン゙成分としてるオキシー2-ナフタイミドおよびその6-ブロム置換体を 用いたすの彷，例克ば XXXVIが啹告されている。

(21) $-\mathrm{SO}_{2} \mathrm{NH}_{2}$ をっているるのこれらは多少可 溶生であるが上述と同じ考点のもとに不溶性染料比分 類した。シアソ成分にスルホンアミド基を有するる の たジソ成分にアシル化スルホンアミド基を有する。 の出)，例衤ばXXXVIIIがある。<smiles>NC(=O)CC1CC2CC[C@@H](C1)C(O)C2NCC1CCC([N+](=O)[O-])CC1</smiles><smiles>CCN(CC)C1CCC(N=NC2CCC(S(N)(=O)=O)CC2)CC1</smiles>

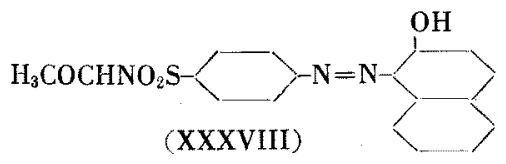

1948年頃迄にはみられなかった新しい部属の染料と してつぎのあのがあり便宜上(1)ペンゾジオキサン基を るつもの，(2)ブチロラタトン環をるつもの（3)核の一 員としてN 3原子あるすの（4)長鎖アルキル基をる。 たすの（5)稱造のはっきりしないもの，の5項目にわ けて記载する。

(22) ベンゾジオキサン基をるつもの ジア・成分 として5ーフミノサリダニンメチレンエーテルを用いた もの45) 48)，例党ば XXXIX 45)，XL年)がありとも黄 色系染料である。ジアゾ成分として4ーフミノピロカテ コールメチレンエーテルを用いたすの47 48，例えば $\mathrm{XLI}{ }^{47)}, \mathrm{XLII}{ }^{48}$ があり黄色系染料である。<smiles>CCCC(O)N=NC1CCC(OC)C(COC)C1</smiles><smiles>OC1CCC(N=NC2CCC3COCCOC3C2)CC1</smiles>

(XL)<smiles>CCCC(O)N=NCCC1OCCCC1OCC</smiles><smiles>OC1CCC(N=NC2CCC3OCCOC3C2)CC1</smiles>

(XLII)

(29) ブチロラクトン環を子つるの アン゙成分とし

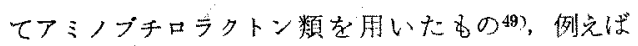
XLIIIがある。

(24) 核の一貝としてN3原于あるもの アン゙成分 としてトリアゾール類を用いたるの，例えばXLIVが ある。

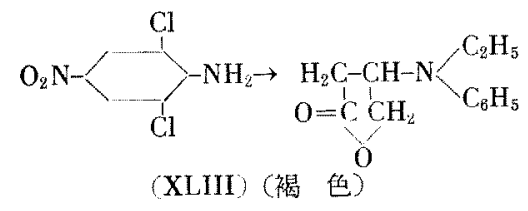




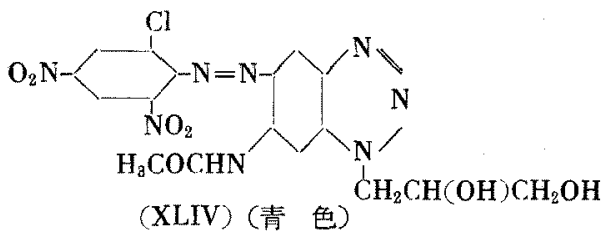

(25) 長銷アルキル基をもっているすのの成分 として長鎖アルキル基をあった いたもの 51 ，長鎖了ルキル基をるったフェノール類を 用いたもの52方ある。

(26) 構造のはっきりしないるの アニリン類とポ リクロルパラフインを縮合せしぬたるのをジン゙成分 としフェノール類をア・゙成分とするすの的，6-ク口 ルー2,4-ジニトロベンゼンーアジ-2'-フセチルアミノ-4'シ( $(\beta$ オキシェチル)アニリンをナトリウムスルホキシ レート・ホルムアルデヒドで還元したすの（青緑色聟

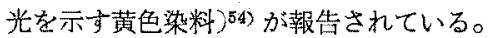

B. 可溶生染料 水溶性の染料としてつぎのものが ある。

(27) 核に一 $-\mathrm{SO}_{3} \mathrm{H}$ をるつもの 特記すべき報告なし。

(28) $\mathrm{NaHSO}_{3}$ で処理した归硫酸エステル 特記す ベき報告なし。

(29) スルファミン酸特記すべき報告なし。

(80) アルキルスルホン酸特記すべき報告なし。

(31) $-\mathrm{OSO}_{3} \mathrm{H}$ をるっているもの（硫酸エステル)

ニトロフェニルーアゾーN- ジフルオルアルキル $-\mathrm{N}-$ オキシエチルアニリンの硫酸エステル55)，例えばXLV があり，さらにアゾ成分としてN-オキシアルキルア ニリン類の硫酸エステルを用いたるの每-60), 例吝ば

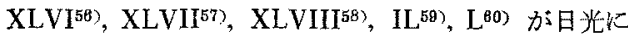
堅窂で抜染可能な染料として報告されている。<smiles>CCNS(=O)(=O)C1CCC([N+](=O)[O-])CC1N=NC1CCC(N(CC(=O)O)CC(F)F)CC1</smiles><smiles>CCCN(CC)C1CCC([N+](=O)[O-])CC1</smiles>

(XLVI) (赤橙色)<smiles>CCOCC(CN(CC)CCC(C)N=NC1CCCC([N+](=O)[O-])CC1)C(=O)O</smiles>

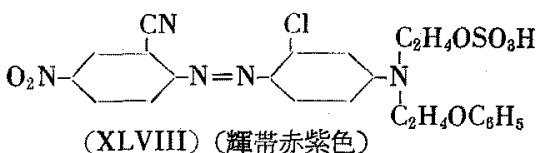<smiles>CCOC(CC)N1CCC(N=NC2CCC([N+](=O)[O-])CC2)CCC1(CC)OS(=O)(=O)O</smiles>

(IL) (䄶色)<smiles>CCN(CCC1C(C#N)CCC([N+](=O)[O-])CC1C#N)C1CCC(N=[N+]=O)CC1</smiles>

(L) (紫 色)

ジアゾ成分に $\mathrm{H}_{2} \mathrm{~N} \cdot \mathrm{C}_{6} \mathrm{H}_{4} \cdot \mathrm{SO}_{2} \mathrm{C}_{2} \mathrm{H}_{4} \mathrm{OH}$ 用いアソ 成分にピラゾロン類を用いて得たモノアン゙染料をスル

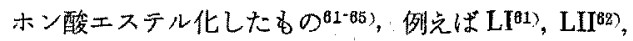

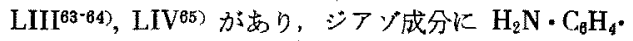
$\mathrm{SO}_{2} \mathrm{C}_{2} \mathrm{H}_{4} \mathrm{OH}$ を用い, アソ成分に p-クレゾールを用い 後スルホン酸エステル化したものの邽)，例光ばLV が報 告されている。<smiles>CCN1C[C@H](N=NC2CCC(S(=O)(=O)O[Na])CC2)C(C)=N1</smiles><smiles></smiles><smiles>CC1=NN(C2CCCC2Cl)OC1N=NC1CCC(S(=O)(=O)OO)CC1</smiles>

$\mathrm{HO}_{3} \mathrm{SOH}_{4} \mathrm{C}_{2} \mathrm{O}_{2} \mathrm{~S}$

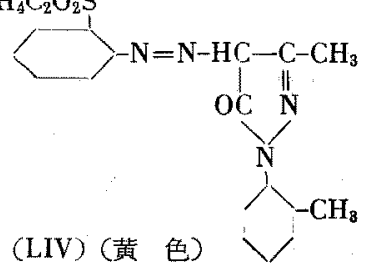


<smiles>CC1CCC(N=NC2CCC(S(=O)(=O)O[Na])CC2)C(O)C1</smiles>

(LV)（黄 色)

さらにジアン゙成分に $\mathrm{p}-\mathrm{H}_{2} \mathrm{~N} \cdot \mathrm{C}_{6} \mathrm{H}_{4} \cdot \mathrm{OC}_{2} \mathrm{H}_{4} \mathrm{OH}$ の硫 酸エステルを用いたるの吕)，例总ばLVIが抜染可能 な染料であると報告されている。

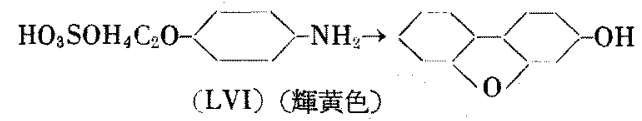

(32) $-\mathrm{SSO}_{3} \mathrm{Na}$ をっているもの(チ才硫酸エステ ル) 特記式にき報告なし。

(3) 核にカルボン酸基をもっているるの ジアゾ 成分にアントラニル酸誘導㑊を，アゾ成分にピラゾロ ン類を用いたすの年，例克ばLVII があり熱，日光， ミーリング等に堅牢である。アゾ成分にアントラニル 酸N-㯰換誘導体を用いたもの帛，例えば LVIIIが報 告されている。

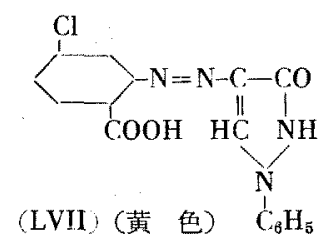<smiles>O=C(O)[Al]1CCC(N=NC2CCCCC2)CCC1N=NC1CCC([N+](=O)[O-])CC1Cl</smiles>

(LVIII) (黄色)

(34) 側鎖にカルボン酸基をbっているもの ジ二 トロアニリン類に，フェニルメチルアミノェチルアル コールKクロルスルホ酷酸を作用せしめたものをカッ プリングさせた毛の70)71》7), $\mathrm{p}$-ニトロフェニルーフソ

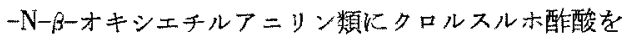
作用させたすの73汴ある。

(35) シカルボン酸のモノェステル４４０ーオキシフ エニルアソ゚ーアニリン類に然水フタル酸74 75!，然水、

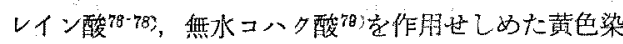
料があり，またアゾ成分中に $\mathrm{N}$ ーター才キンェチル基を

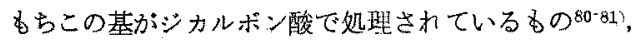
们えば $\mathrm{LIX}^{80}$ ， LX ${ }^{81)}$ がある。<smiles>CCCN(CC)C1CCCC(N=NC2C(Cl)CC([N+](=O)[O-])CC2Cl)CC1</smiles>

（ILX）（推定篟造）（橙色）

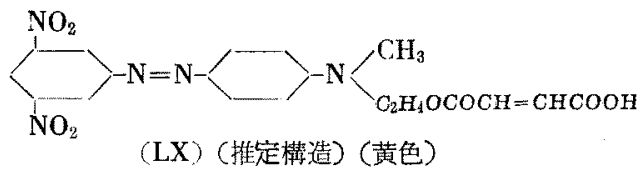

さらにシアゾ成分に $\mathrm{p}-\mathrm{H}_{2} \mathrm{~N} \cdot \mathrm{C}_{6} \mathrm{H}_{4} \cdot \mathrm{SO}_{2} \mathrm{C}_{2} \mathrm{H}_{4} \mathrm{OH}$ を, アゾ成分に1-(2'-クロルフェニル)-3-メチルー5-ピラ ゾロンを用いた染粕を無水マレイン酸 ${ }^{822}$ ，無水コハ ク酸的で処理した黄色染料が報告されている。

(36) リン酸基をもっているるの 特記すべき報告 なし。

[II] ジスアソ染料 A. 不溶性染将 8485 ，B. 可溶性 染料䀶があるがこれについては特記すべき報告がない、

これらはすべて特許文献であり，この他 Y.Arnould $^{87)}$, H. Gilman $5^{88789)}$, J. B. Dickey $5^{80)}$, 林

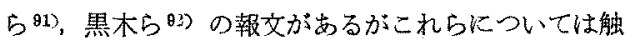
れないことにする。（昭和31年2月17日哞理）

文 献

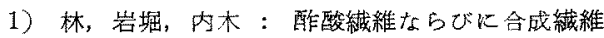
用染料，下甞 (昭29) (技報堂)

2) Swiss $236,997(1945)$ : C. A., 43, 8689 (1949)

3) Swiss $287,130(1945)$; C. A., 43, 8689 (1949)

4) U. S. $2,475,228$ (1949)

5) Swiss $234,786(1945)$

6) Swiss 257,032 (1949) ; C. A., 44, 6138 (1950)

7) U. S. $2,491,481$ (1949) ; C. A.. 44, 8120 (19 50)

8) U. S. $2,618,631$ (1952) ; C. A., 47, 4097 (19 53)

9) U. S. $2,492,972(1950)$

$10)$ U. S. $2,516,302$ (1950); C. A., 45, 8253 (19 51)

11) U. S. $2,590,092$ (1952) ; C. A., 46,5856 (19 $52)$

12). U. S. $2,618,630(1952)$; C. A., $47,4096 \sim 7$ (1958)

13) U. S. $2,615,013(1952)$; C. A., $47,4620 \sim 1$ 1953 ,

14) U. S. $2,594,297,1952)$; C. A., 46, 8864(1952) 
15) Brit. 721,632 (1955)

16) Brit. 731,448 (1955)

17) U. S. $2,492,972(1950)$

18 U. S. $2,649,440(1953)$; C. A., $48,383(1954)$

19) Ger. 927,286 (1955) ; C. A.. 49, $12842(1955)$

20) Brit. 676,721 (1952)

21) Fr. 965,973 (1950) ; C. A., 46, 3287 (1952)

22) Ger. 888,290 (1953) ; C. A., 48, 7308 (1954)

23) U. S. $2,470,094(1949)$; C. A., 43, 9461(1949)

24) Brit. 722,474 (1955)

25) U. S. $2,448,871$ (1948) ; C. A., 43, 861 2 (1949)

26) U. S. $2,649,440(1953)$; C. A., 48, 383(1954)

27) Brit. 723.933 (1955)

28 ) U. S. $2,659.719(1953)$; C. A., 49, 1335 (1955)

29 U. S. $2,688,708(1954)$; C. A., 49, 1336(1955)

30) U. S. $2,683,709(1954)$; C. A., 49, 1336 7 (1955)

31) Ger. 927,944 (1955) ; C. A., 49, 12842 (1955)

32) U. S. $2,683,709$ (1955) ; C. A., 49, 1336 7 (1955)

33) Brit. 666,057 (1952) ; C. A., 46, 5326 (1952)

34) U. S. 2,590,639(1952) ; C. A., 46, 5854(1952)

$35)$ U. S. $2,590,640(1952)$; C. A., 46, 5854(1952)

36 U. S. $2,559,181(1951)$; C. A., $45,9869(1951)$

37) U. S. 2,529,924(1950) ; C. A., 45, 2676(1951)

38) U. S. $2,448,871$ (1948) ; C. A., 43, 861 2 (1949)

39) U. S. $2,448,869$ (1948) ; C. A., 43, 2781 2 (1950)

$40)$ U. S. $2,578,290(1951)$

$41)$ U. S. $2,469,682(1949)$; C. A., 44, 4684(1950)

42) Ger. 888,990 (1953) ; C. A., 48, 13229 (1954)

43) Brit. 664,258 (1952) ; C. A., 46, 6395 (1952)

44) Ger. 892,809 (1953) ; C. A., 48, 13228 (1954)

45) Swiss 236,532 (1945) ; C. A., 43, 5194 (1949)

$46)$ U. S. $2,468,277(1949)$; C. A., 43, 8149(1949)

47) Swiss 233,846 (1944) ; C. A., 43, 7697(1949)

48) Swiss 286,583 (1945) ; C. A., 43, 5194(1949)

49) Ger. 916,968 (1954) ; C. A., 49, 1334 (1955)

50 ) U. S. $2,448,870(1948)$; C. A. $43,3625 \sim 3626$ (1949)

51) Ger. 836,383 (1952) ; C. A., 46, 8863 (1952)
52) U. S. $2,489,384(1949)$; C. A., $44,6138(1950)$

53) U. S. $2,593,406(1952)$; C. A., 46, 6841(1952)

54) U. S. $2,433,939$ (1948)

55) U. S. 2,615,014(1952) ; C, A., 47, 2501(1953)

56) Brit. 588,410 (1948)

57) Brit. 588,409 (1948)

$58)$ U. S. $2,474,737(1949)$; C. A., $43,8155(1949)$

$59)$ U. S. $2,473.885(1949)$; C. A., 43, 8154(1949)

60) Swiss 283,187 (1944) ; C. A., 43, 9458 (1949)

61) Swiss 238,461 (1945) ; C. A., 43, 8146 (1949)

62) Swiss 238,462 (1945) ; C. A., 43, 8146 (1949)

63) Swiss 238,465 (1945) ; C. A., 43, 8153 (1949)

64) Swiss 238,764 (1945) ; C. A., 43, 7235 (1949)

65) Swiss $238,466(1945)$; C. A., 43, 8153 (1949)

66) Swiss $238,460(1945)$; C. A., 43, 8146 (1949)

67) Brit. 596,280 (1948)

68) Brit. 691,475(1953); C. A., 47, 10235 (1953)

69 ) Brit. 632,096 (1949) ; C. A., 44, 6137 (1950)

70) Swiss 238,624 (1945) ; C. A., 43, 4471 (1949)

71) Swiss 238,625 (1945) ; C. A., 43, 4471 (1949)

72) Swiss $238,626(1945)$; C. A., 43, 4471 (1949)

73) Swiss 227,510 (1948); C. A., 43, 4019 20 (1949)

74) Swiss 231,411 (1944) ; C. A., 43, 4475 (1949)

75) Swiss $231,409(1944)$; C. A., 43, 4475 (1949)

76) Swiss $231,412(1944)$; C. A., 43, 4475 (1949)

77) Swiss $231,410(1944)$; C. A., 43, 4475 (1949)

78) Swiss 229,185 (1944) ; C. A., 43, 4474 (1949)

79) Swiss 231,413(1944); C. A., 43, 4475 (1949)

80) Swiss 238,623 (1945) ; C. A., 43, 4471 (1949)

81) Swiss 226,018 (1943) ; C. A., 43, $7696(1949)$

82) Swiss $238,464(1945)$; C. A., 43, $8153(1949)$

83) Swiss $238,463(1945)$; C. A., 43, 8153 (1949)

84) Ger. 921,404 (1954) ; C. A., 49, 5850 (1955)

$85)$ U. S. $2,563,091(1951)$; C. A., 45, 10600 10 601 (1951)

86) Brit. 609,275 (1948) ; C. A., 43, 7695 (1949)

87) Y. Arnould et al : Bull. Soc. Chim., France $491 \sim 3 \quad(1951) ; 366 \sim 9(1952)$

88) H. Gilman et al: Text. Res. J. 22, $574 \sim 83$ (1952)

89) H. Gilman et al : ibid., 23, 53 8 (1953)

90) J. B. Dickey et al. : Ind. Eng. Chem., 45, $1730 \sim 4$ (1953)

91）林, 石川：有機合成化学, 12，213 21 (1954)

92）黑木等：派大学報, 2 A. 213 40 (1954) 